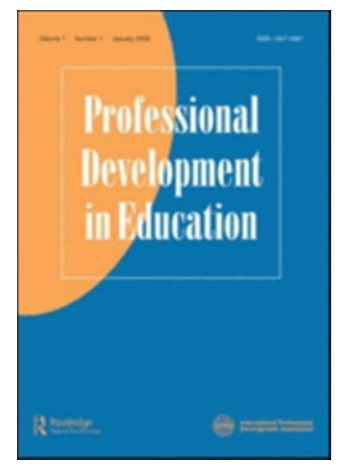

\title{
The Professional Development of Higher Education-Based Teacher Educators: Needs and Realities
}

\begin{tabular}{|r|l|}
\hline Journal: & Professional Development in Education \\
\hline Manuscript ID & RJIE-2018-0092.R2 \\
\hline Kanuscript Type: & Original Article \\
\hline Keywords: & teacher educators, professional learning, professional development \\
\hline & $\begin{array}{l}\text { Current literature suggests that while teacher educators perform a } \\
\text { multitude of complex roles, they receive very little preparation or } \\
\text { possibilities for professional development to fulfil these roles. As a result, } \\
\text { they need to acquire relevant knowledge and skills after taking on the } \\
\text { position of teacher educators. Therefore, it is important to learn what skills } \\
\text { and knowledge teacher educators need and how they acquire such skills } \\
\text { and knowledge throughout their career. The purpose of the study is to } \\
\text { describe the professional development needs and activities of } 61 \text { teacher } \\
\text { educators across six national jurisdictions (England, Ireland, Israel, } \\
\text { Norway, Scotland, The Netherlands) and to reveal influencing factors and } \\
\text { affordances conducive to professional development. Semi-structured } \\
\text { interviews constituted questions on professional learning opportunities and } \\
\text { teacher education and research. Results from the interviews convey } \\
\text { themes around the areas of (i) self-initiated professional development, (ii) } \\
\text { the importance of experiencing professional development through } \\
\text { collaboration with peers and colleagues (iii) accessing opportunities to } \\
\text { improve teacher education teaching practices, and (iv) the inextricable link } \\
\text { between teaching and research and consequently the need to upskill in } \\
\text { research skills. Discussion points that arise include the induction period, } \\
\text { frustration and tension in navigation, haphazard professional learning and } \\
\text { learning with and from each other. }\end{array}$ \\
\hline
\end{tabular}

\section{SCHOLARONE}

Manuscripts 


\begin{tabular}{|c|c|c|c|c|c|}
\hline Jurisdiction & $\begin{array}{c}\text { Gender } \\
\text { (Female / } \\
\text { Male) }\end{array}$ & $\begin{array}{l}\text { Age group } \\
\text { (years) }\end{array}$ & $\begin{array}{c}\text { Range of } \\
\text { experience as a } \\
\text { school teacher }\end{array}$ & $\begin{array}{c}\text { Range of } \\
\text { experience as a } \\
\text { teacher } \\
\text { educator }\end{array}$ & $\begin{array}{c}\text { Current institute } \\
\text { (University / } \\
\text { College) }\end{array}$ \\
\hline England & $9 / 6$ & $\begin{array}{l}\text { 25-34: } 2 \\
35-44: 4 \\
45-54: 7 \\
55-64: 2\end{array}$ & 4 to 34 years & 7 to 24 years & $15 / 0$ \\
\hline Ireland & $7 / 3$ & $\begin{array}{l}\text { 25-34: } 1 \\
35-44: 2 \\
45-54: 3 \\
55-64: 4\end{array}$ & 1 to 20 years & 6 to 29 years & $6 / 4$ \\
\hline Israel & $8 / 2$ & $\begin{array}{l}\text { 25-34: } 0 \\
\text { 35-44: } 0 \\
\text { 45-54: } 4 \\
\text { 55-64: } 2 \\
\text { 65-74: } 4\end{array}$ & 3 to 20 years & 6 to 33 years & $0 / 10$ \\
\hline Norway & $8 / 2$ & $\begin{array}{l}\text { 25-34: } 1 \\
\text { 35-44: } 3 \\
\text { 45-54: } 3 \\
\text { 55-64: } 3\end{array}$ & 0 to 25 years & $\begin{array}{c}6 \text { months to } 26 \\
\text { years }\end{array}$ & $6 / 4$ \\
\hline Scotland & $8 / 3$ & $\begin{array}{l}\text { 25-34: } 0 \\
\text { 35-44: } 2 \\
\text { 45-54: } 3 \\
\text { 55-64: } 5 \\
\text { 65-74: } 1\end{array}$ & 2 to 28 years & 3 to 20 years & $11 / 0$ \\
\hline $\begin{array}{c}\text { The } \\
\text { Netherlands }\end{array}$ & $4 / 1$ & $\begin{array}{l}\text { 25-34: } 1 \\
\text { 35-44: } 2 \\
\text { 45-54: } 1 \\
\text { 55-64: } 1\end{array}$ & 0 to 25 years & 2 to 19 years & $2 / 3$ \\
\hline
\end{tabular}

Table 1: Demographics for the sample of teacher educators across six jurisdictions 
The Professional Development of Higher Education-Based Teacher Educators: Needs and Realities

\title{
The Professional Development of Higher Education-Based Teacher Educators: Needs and
}

\section{Realities}

\begin{abstract}
Current literature suggests that while teacher educators perform a multitude of complex roles, they receive minimal preparation or possibilities for professional development to fulfil these roles. As a result, they need to acquire relevant knowledge and skills after taking on the position of teacher educators. Therefore, it is important to learn what skills and knowledge teacher educators need and how they acquire such skills and knowledge throughout their career. The purpose of the study is to describe the professional development needs and activities of 61 teacher educators across six national jurisdictions (England, Ireland, Israel, Norway, Scotland, The Netherlands) and to reveal influencing factors and affordances conducive to professional development. Semi-structured interviews constituted questions on professional learning opportunities and teacher education and research. Results from the interviews convey themes around the areas of (i) self-initiated professional development, (ii) the importance of experiencing professional development through collaboration with peers and colleagues, (iii) accessing opportunities to improve teacher education teaching practices and (iv) the inextricable link between teaching and research and consequently the need to upskill in research skills. Discussion points that arise include the induction period, frustration and tension in navigation, haphazard professional learning and learning with, and from, each other.
\end{abstract}

Key words: teacher educators; professional learning; professional development 
The Professional Development of Higher Education-Based Teacher Educators: Needs and Realities

\section{Introduction}

Teacher education quality has been acknowledged as an important factor influencing the quality of teaching and students' achievements (European Commission 2013). As a result, there has been a growing interest in teacher educators: their identity, skills, roles and professional development (Loughran 2014, Lunenberg et al. 2014). While teacher educators can be defined as those who are involved in the education of student teachers as well as continued professional development of in-service teachers (European Commission, 2013, Czerniawski et al. 2017), the current paper deals with teacher educators who work in higher education institutes (as distinct from teacher educators based in schools). Current literature suggests that while teacher educators perform a multitude of complex roles, they receive minimal preparation or possibilities for professional development to fulfil these roles. As a result, they need to acquire relevant knowledge and skills after taking on the position of teacher educators (Murray \& Male 2005, Smith 2011). Therefore, it is important to learn what skills and knowledge teacher educators need and how they acquire such skills and knowledge throughout their career. The purpose of the current study is to describe the professional development needs and activities of teacher educators across six national jurisdictions and to reveal influencing factors and affordances conducive to professional development.

\section{The Professional Roles of Teacher Educators}

Teacher educators perform diverse roles, each of which requires professional learning and development (Murray 2010, Swennen et al. 2010, Lunenberg et al. 2014). Teacher educators need to be expert teachers, 'developing expertise in making informed decisions about practice in ways that are responsive to complex situations based on sophisticated knowledge and thinking' 
The Professional Development of Higher Education-Based Teacher Educators: Needs and Realities

(Loughran \& Hamilton 2016, p. 6). Teaching adult learners at higher education institutes involves a different approach to teaching than teaching students in schools (Lunenberg et al. 2014). In defining the pedagogy of teacher education, Loughran (2014) suggests two complementary aspects: learning about teaching and teaching how to teach (i.e., 'second order teaching'). To support their students, teacher educators must be aware of the ways in which their students learn about teaching from their own experience. The pedagogy of effective teacher education also aims to challenge student teachers' preconceptions of teaching based on their experiences as students in schools. As for second order teaching, teacher educators serve as role models to their students (Russel, 1997, Loughran, \& Hamilton 2016). However, setting a good example is not enough. Teacher educators need to formulate their implicit deliberations and 'know how' of teaching in an explicit manner, forming linkages between theory, previous research, current experience and their students' future teaching. As Lunenberg et al. (2007) convey, teacher educators may not have the required knowledge, skills and emotional willingness to risk exposing their insecurities and mistakes in front of their students. Furthermore, to support student teachers' professional development, teacher educators need to be engaged in deep reflection that involves scrutiny and clarification of their own educational beliefs, values and mission (Korthagen \& Vasalos 2005, Loughran 2014, Loughran \& Hamilton 2016).

Research and teaching are connected in more than one way. Effective teacher educators are increasingly expected by their institutes to be critical readers of research, basing their teaching on the accumulated knowledge and experience of the professional teaching community (Murray et al. 2009, Elstad 2010, Loughran 2014). In addition, many academic institutes expect teacher 
The Professional Development of Higher Education-Based Teacher Educators: Needs and Realities

educators to contribute to the development of knowledge in their field through their own research (Zeichner 2007, Lunenberg et al. 2014). Authors underline teacher educators' simultaneous roles as researchers and practitioners and suggest that researching their own practice is one way to connect the two roles (Cochran-Smith 2005, Lunenberg et al. 2014, Smith 2015). Researching their own practice (either individually or collaboratively) raises teacher educators' awareness of possible mismatches between their mission and beliefs and their actual practice, and enables them to explore new ways of teaching in relation to their students' learning (Cochran-Smith 2005, Murray 2010). Such research may challenge 'taken for granted' conceptualizations and practices, and thus transform teacher education rather than add improvements to the current system (Loughran 2014). Active participation in research is a model of life-long learning to student teachers (Lunenberg et al. 2007). While this situation captures the ideal scenario, this may not always play out in practice and subsequently has implications for the types of professional development teacher educators are expected to engage in.

Teacher educators work in 'borderline areas' between academia, schools, local authorities and communities, where they act as mediators (Lunenberg et al. 2014). The contexts of their work include individual professional backgrounds and a diversity of institutional and national contexts. These influence their work, task-perception, identities and positions, as well as their professional development needs and opportunities (Murray 2014). For example, teacher educators are usually recruited from two sources, working either as teachers in schools or as researchers in universities (Vanassche et al. 2015). Former teachers need to be introduced into research, whereas researchers may lack teaching skills. Given the complexity of the profession on the one hand, and the lack of abiding entry requirements and pre-service preparation on the other hand 
The Professional Development of Higher Education-Based Teacher Educators: Needs and Realities

(Goodwin et al. 2014), professional development is essential for teacher education quality (BERA \& RSA 2014).

\section{The Professional Development of Teacher Educators}

The majority of studies dealing with teacher educators' professional development discuss the effects of specific activities over a relatively short time period, and many focus on beginning teacher educators (for example, Murray \& Male 2005, Berry 2007, Loughran 2013, Murray 2014). There is a dearth of research that provides an exploration of the professional learning activities of teacher educators throughout their career. One exception is Smith (2017), who describes her career trajectory with the intention of highlighting lessons that may be used to shape future opportunities for teacher educators' professional development. Smith (2017) reports that two major factors enhanced her professional development: (1) self-initiation and determination to move out of her comfort zone and seek new challenges and (2) collaboration with colleagues. Another exception is a recently published cross-national study (Van der Klink et al. 2017) that explored teacher educators' concerns and professional development activities during their induction period and as experienced teacher educators. The study describes a variety of professional development activities in which teacher educators engage, such as participation in formal study programmes, informal consultations with colleagues and conducting research. Similar with Smith (2017), they point to personal motivation and needs as the driving forces that enhance professional development. The main obstacles hindering participation in professional development activities are lack of time and work overload, a finding that also emerged in a large international survey of teacher educators' professional development needs (Czerniawski et al. 2017). Nevertheless, the factors that influence participation in professional development 
The Professional Development of Higher Education-Based Teacher Educators: Needs and Realities

activities are described in general terms that do not expose the specific influencing factors that are associated with each of the activities. The study reported in this paper acknowledges this gap. It explores the professional development needs and activities of a sample of teacher educators over seven national jurisdictions, attempting to gain insight in professional development activities aimed at addressing the needs of teacher educators. Identifying such influencing factors is a first step towards the formation of effective opportunities for teacher educators' professional development.

'Professional learning' is different from the traditional definition of 'professional development'. Professional learning constitutes the learning that is undertaken on a daily basis embedded within the remit of fulfilling the role as a teacher / teacher educator is underpinned by research and practice-based evidence and supported by a professional learning community (Berry et al. 2007). Professional development tends to refer to 'formal courses' and there has been criticism of such efforts where these opportunities are one-off events, providing little or no follow-up support (Mockler 2005). While the focus of this paper is professional learning, the distinction between the two terms is not always explicitly evident across the literature and therefore, in reporting related research, in some cases, the two terms are used interchangeably.

\section{The Context of the Study}

The study was conducted by members of InFo-TED (International Forum for Teacher Educator Development). InFo-TED is a group of experienced teacher educators from seven national jurisdictions (England, Flanders, Ireland, Israel, Norway, Scotland and The Netherlands). Flanders is not included in the study reported here. The group was formed to promote international, as well as national, initiatives to support the professional development of teacher 
The Professional Development of Higher Education-Based Teacher Educators: Needs and Realities

educators (Vanassche et al. 2015, Kelchtermans et al. 2018). One of the group's first actions was to conduct a professional development needs survey, to which over a thousand higher educationbased teachers educators responded (Czerniawski et al. 2017). The survey found that teacher educators value professional learning and are interested in participating in professional development activities. In the survey, professional development preferences could be clearly divided into two distinct types. The first type related to improving research skills, such as scholarly writing and presenting at conferences. The second type was associated with educational capacities, e.g., learning about current developments in teacher education, or assessment methods. The first type was more prevalent among teacher educators with $\mathrm{PhDs}$, whereas the second type was characteristic of teacher educators with a Master's qualification. The distinction may imply that teacher educators follow specific professional development trajectories that are related to, and a continuation of, their recruitment into teacher education either from the universities or from schools (Vanassche et al. 2015). In this paper we look deeper into teacher educators' professional development activities, aimed at addressing their professional needs. That is, how they conceive of these needs, what opportunities they have, and what influences participation in professional development activities.

\section{Methods}

\section{Participants}

A sample of 61 higher education teacher educators (15 from England; 10 from each of three countries - Ireland, Israel, Norway; 11 from Scotland; 5 from The Netherlands) were sourced after completing the European survey noted in the above section that set out to establish the professional learning experiences and needs of higher education-based teacher educators. Each 
The Professional Development of Higher Education-Based Teacher Educators: Needs and Realities

of these teacher educators noted their interest in being involved further in the study. The sample of teacher educators in this study resulted in a range of demographics across age, gender, qualifications, years of experience as a teacher, years of experience as a teacher educator, academic roles and responsibilities and future aspirations as a teacher educator. Demographics for the sample of teacher educators are noted in Table 1.

A limitation of this study is the small and self-selected sample from each of the participating jurisdictions.

[Insert Table 1 here]

\section{Interviews}

The semi-structured interview protocol was piloted with teacher educators who were not part of the study sample. The pilot was conducted to ensure the wording and spirit of the questions being posed translated and transferred appropriately across numerous geographical and language contexts. Those who were responsible for conducting the pilot studies were the same individuals who conducted the main study semi-structured interviews, which allowed for a level of consistency in the presentation of the interview protocol across the countries. The interview questions closely mapped the sections of the previously completed survey and constituted questions on (i) background and demographics, (ii) professional learning opportunities and (iii) teacher education and research. Interviews were conducted in each participant's native language in a setting of their choosing, with interviewees providing informed consent for the interviews. Interviews lasted between 35 minutes and 90 minutes. Each interview was transcribed in the language in which they were conducted. 
The Professional Development of Higher Education-Based Teacher Educators: Needs and Realities

\section{Data analysis}

The interview data were analyzed thematically. Initially, the researchers in each of the six jurisdictions identified themes related to professional development opportunities arising from their specific country interviews. A coding process, used in identifying similar text units, followed by linking and retrieval of similarly coded segments (Mason 1996), was standardized across the six jurisdictions. These were arranged under specific themes and the data was analyzed under these themes aligned with the professional development opportunities of teacher educators. New themes that emerged necessitated further consideration and analysis of previously coded data. Four themes that were prevalent across the six jurisdictions (albeit to varying extents) are now explored in the results section. Quotations have been selected from the higher education-based teacher educators across the six jurisdictions and from varying degrees of experience. The chosen quotations will provide the reader with the teacher educator voice to reinforce the main observations.

\section{Results}

Results from the higher education-based teacher educators' interviews convey themes around the areas of (i) self-initiated professional development, (ii) the importance of experiencing professional development through collaboration with peers and colleagues, (iii) accessing opportunities to improve teacher education teaching practices and (iv) the inextricable link between teaching and research and consequently the need to upskill in research skills.

\section{Self-initiated Professional Development}


The Professional Development of Higher Education-Based Teacher Educators: Needs and Realities

Teacher educators entered teacher education with a variety of backgrounds and needs. It was consistently clear across all countries that teacher educators' professional development was predominantly self-initiated. Independent of background, enacting teacher education was different to what individuals had experienced before, with a level of vagueness and ambiguity on what was expected from them. In some instances, this resulted in teacher educators believing they lacked a specific skill-set required to be an effective teacher educator. This is captured most succinctly by one teacher educator;

“(...) then you are hired and then you are expected to be able to do everything and that is difficult in the beginning at times (...) things are expected of me. Things of which I actually estimate that I do not know that very well but apparently I should be able to do it"' (The Netherlands).

Across most institutes there was a lack of opportunity to pursue professional development specific to teacher education and teacher educators. Professional development opportunities targeted at more generic teaching in higher education audiences heightened the need for teacher educators' development to be self-initiated. One teacher educator commented on the more generic audiences for professional learning opportunities, at the expense of a dearth of professional learning opportunities for teacher educators, “(...) my level of satisfaction wouldn't be as high with the generic opportunities that are afforded to academics generally" (Ireland).

In order to develop as teacher educators, the interviewees explained how and why they had initiated their own professional development experiences; "There are no professional development opportunities unless you devise them yourself" (Israel) and "(...) mainly the 
The Professional Development of Higher Education-Based Teacher Educators: Needs and Realities

motivation has been personal satisfaction, taking control and ownership over my personal development which I was always told was a key feature of the job” (England).

Teacher educators were, furthermore, proactive in accessing professional development opportunities in and outside of their own institutes, "I'm very much a self-starter in that respect (...) if I need to do something I generally know the University's procedures well enough that I can go and find out about it" (Scotland) and "It's not just the institution [professional development opportunities]. I gain knowledge from any opportunity. Last year after masterclasses delivered by international speakers (...) I gained something from each" (The Netherlands).

The Importance of Experiencing Professional Development through Collaboration with Peers and Colleagues

An important source related to professional development was collaboration with others. Three main areas arose under this heading and included the appreciation from mentees of being mentored by more experienced colleagues, working together / collaboratively with colleagues and becoming a mentor to those new to teacher education.

Viewing other teacher educators as mentors on entering teacher education as a beginning teacher educator was commonly depicted as a meaningful learning experience, "When I arrived at the college it was after the academic year had already started and I didn't know anything, really nothing at all. But there were two adjacent instructors that supported me tremendously, all along the way, and that's how I reached my current position" (Israel) and "I got a mentor my first year in teacher education. He got some extra time for supporting me (Norway). While the quotes 
The Professional Development of Higher Education-Based Teacher Educators: Needs and Realities

convey the appreciation by teacher educators of an appointed mentor, the interview data suggests that such an opportunity was rare.

Connecting with colleagues informally was also deemed a stimulating experience, "I was lucky to work with a teacher educator who I worked with for a long time (...) just discussing difficult things that you encounter (...) more informal" (The Netherlands) and "I don't always get the opportunities I'd like to hear what my own colleagues are doing and they are doing fine work as well. Whether that's even an informal coffee conversation, I find that very valuable" (Ireland). It appeared to be supportive conditions for professional dialogue than formalized opportunities to up-skill in a particular topic that was most valued, "I need informal conditions often rather than formal conditions, for my professional learning to occur. I might need help every once in a while, I might need some motivation, I might need to get with a group” (Ireland).

Having access to a community of teacher educators was consistently reported as an effective and preferred means of experiencing professional development, “(...) a community is very important. A community of people with whom you can discuss current affairs, where you can discuss things and where you can compare your practices to others" (The Netherlands). However, teacher educators were cautious in their expectations of what colleagues with demanding job remits could feasibly contribute to with respect to collaborative community support, "It feels too difficult to carve out staff time or resources for it or to ask other people to collaborate because you know that they will be collaborating over and above their normal responsibility" (Scotland). Consequently, even if informal support in a community is valued, it has its challenges.

The opportunity to co-teach was referenced by one Norwegian teacher educator as an invaluable opportunity when starting to work in a new institute in a bid to ensure a level of quality teaching, 
The Professional Development of Higher Education-Based Teacher Educators: Needs and Realities

"I had the great advantage of having a colleague who was there all the time and knew the modules and the organization. I have been newcomer in other jobs without the same benefit (Norway). Some teacher educators in Norway experienced interdisciplinary co-teaching and one even co-taught across countries. Such experiences were noted as invaluable for their professional development as a teacher educator due to being introduced to new perspectives and challenging their own teacher education practices. However, there was an awareness from the Norwegian teacher educators that, given the expense of co-teaching and a current emphasis on supporting and producing research outputs, co-teaching was no longer a common practice across teacher education programmes.

Collaboration with teacher educators in other European institutes and countries heighted professional learning opportunities. In Ireland, the collaboration amongst teacher educators in one institute and teacher educators in other European institutes was heighted by those who were actively part of European project consortiums. This collaboration was further supported by Norwegian teacher educators who acknowledged that there was not always the opportunity to learn from teacher educator peers in your own institute with respect to research activity. One teacher educator explained she was the only teacher educator within her field of expertise with a $\mathrm{PhD}$ and, subsequently, had to explore opportunities to learn from peers in other jurisdictions, " $I$ am formally supported, but need a research environment, because there is no environment related to my subject at this institution" (Norway).

There was an admittance that cooperation and collaboration can be challenging with respect to criticism and competition, "My [preference for] learning with colleagues in environments that tend to be challenging but safe (...) looking at the notion of learning environments that will push 
The Professional Development of Higher Education-Based Teacher Educators: Needs and Realities

and pull but are not judgmental" (Ireland) and "Among my colleagues I'm supported by some, but there's a kind of competition" (Norway). In the latter context, the teacher educator explained that other teacher educators envied the opportunities she had been given and subsequently a distance had been created between her and some of her colleagues. Another teacher educator noted how teacher educators' competing time commitments can result in working collaboratively as more of a barrier to development than if you are working on your own, “(...) collaboration can be a barrier because if it was just me [working on the project] I'd just get on and do it" (England).

Within our sample, very few teacher educators mentored other teacher educators. Those who did found the experience rewarding and enriching;

"I guide an amazing researcher. We conduct inter-cultural research. Inter-cultural research allows me to learn, to know the other (...) We are currently working on the first paper. It is very important for him to publish, and it is very important for me that he will publish (...) I also learn from my post-doctoral student. Very much” (Israel).

While teacher educators had gained from being supported by more experienced colleagues, there appeared to be no formalised opportunity for teacher educators to study how best to support colleagues, "I've worked with lots of very experienced teacher educators at different stages in my career, and I've learned a lot from them... I have not had any formal education opportunities for educating teachers" (Scotland).

\section{Accessing Opportunities to Improve Teacher Education Teaching Practices}


The Professional Development of Higher Education-Based Teacher Educators: Needs and Realities

There was a genuine interest from teacher educators in all contexts to continually improve their teaching practices.

It is important that we acknowledge that not all those who identify as teacher educators have undertaken a teacher education related degree, whether as an undergraduate or at postgraduate level. In such instances, it is common that while these specific teacher educators deliver the technical and scientific content, the pedagogy element is delivered elsewhere on the programme and subsequently student teachers are left to merge the two. Consequently, opportunities run by higher education institutes for staff to formally upskill in scholarship and teaching is targeted at those who have undertaken academic roles where part of their responsibility is to teach their specific subject expertise to teacher education students. This not only provides an opportunity to improve their teacher 'education' practices but also, "to meet people and talk and experience what other people are doing" (Ireland). Nevertheless, teacher educators commented that a significant amount of opportunities provided by their institutes to upskill on innovative pedagogies were predominantly aimed at staff who were not teacher educators and, consequently, such opportunities appeared "simplistic" to teacher educators (Ireland).

The majority of teacher educators implied that insufficient affordances were offered in developing their teaching, "I still feel they're [teacher education practices] kind of traditional, the ways of doing it, the lecturing (...) and lack of resources, always (...) and we don't have the opportunities to develop our own teaching in the teacher education as much as I'd like to" (Norway). A lack of resources and operational frameworks hindered teacher educators developing their teaching, "There are no plans for developing our teaching except when it comes to digital tools. I work with it on my own or in cooperation with others" (Norway). Insufficient 
The Professional Development of Higher Education-Based Teacher Educators: Needs and Realities

affordances were heightened with the admittance that effective pedagogies were continually developing and needed to be aligned with the changing contexts of schools.

Appreciating the difficulty of prioritising time as a teacher educator, there was an interest from teacher educators that they be supported to return to school for a period of time to practice as a school teacher and experience the reality of being part of the teaching profession, “(...) every day that I work at university it's one day longer since I worked in schools. The gap between 'walking the walk' and 'talking the talk' is getting bigger (...) need to spend times in schools remembering what the job is" (England). The opportunity for teacher educators to visit schools to observe student teachers on school placement had been removed for some teacher educators, resulting in teacher educators feeling somewhat removed from the reality of teaching, "it's [school placement] shared knowledge, it's new knowledge, it's a dialogue space you know and there are opportunities for joint research as well and that has been removed now" (Scotland).

Although teacher educators expressed a strong desire to improve their professional capacity as teachers, their professional development activities in this realm tended to be self-initiated, and gained minimal currency in academia;

"I have already developed my teaching. It is one of the main activities for me, but there is no pay off in teaching. I have been nominated as the teacher of the year in my institution several times. The most important for me is that students find the teaching meaningful, but the system gives no credit for teaching. You are encouraged to publish" (Norway).

The Need to Upskill in Research Skills 
The Professional Development of Higher Education-Based Teacher Educators: Needs and Realities

There is an inextricable link between teaching and research. Teacher educators were unanimous in the need to keep abreast of recent developments that would inform their teaching. "I want to ensure that my teaching is both research-informed and evidence based. In order to do that, I need to do whatever I can to try and keep abreast of any recent developments" (Ireland), "I think if I had excellence as a teacher without research I'd be missing a piece of the jigsaw” (England) and;

"If there is no research in your practice as a teacher / educator then I would question whether you are a teacher / educator or a teacher / trainer and to what extent what you are doing goes beyond "tips for teachers". If there is no use of research to inform what you're doing then that's training not education" (England).

Acknowledging that they may not have the time to read the volumes of research publications, there was a preference for attending professional colloquia or conferences that would expose them to recent developments within a relatively short period of time.

Opinions diverged on whether teacher educators need to be active researchers. Some teacher educators were recruited from the research field and enjoyed doing research. There was a consensus that contractual obligations as a teacher educator in a university resulted in research being part of teacher educators' remit as well as legitimacy, "Research is very important in teacher education. It has to do with legitimacy" (Israel) and "It's in my job descriptor and it is fundamental, ... I mean it is there in black and white that I have a responsibility to carryout research and to write up that research as part of what I do" (Scotland). 
The Professional Development of Higher Education-Based Teacher Educators: Needs and Realities

Some teacher educators noted how their involvement in research would benefit the teaching and teachers of a specific school subject, "Research is the key way to develop the knowledge we want to develop, be able to conceptualize it, pack it, understand what we actually learn” (Israel) and;

"You cannot be a good teacher educator without doing research. We need a lot of research about how to teach mathematic that is less frightening and more motivating and useful for students in school. That is what I want to be involved with. My research should be of benefit to math teachers in school" (Norway).

Being a researcher and at the same time a practitioner was for some teacher educators a pleasure of their work;

However, I enjoy what I am doing in this job. I am allowed to be the nerd that study texts in Latin and work with the antiquity - something that no-one has time for or can afford today. At the same time I can be a teacher educator and do something that is important to people around me. I have never thought it could be possible to have a job where I could do both. So sometimes I am so excited when I think about how lucky I am (Norway).

A significant amount of teacher educators had begun as teacher educators without a PhD. The increasing pressures from institutes to employee teacher educators with $\mathrm{PhDs}$ led many to undertake PhD studies. Subsequently, they were able to articulate the benefits of being research literate, "So research is very important, and more and more, of course. When I started as a teacher educator, it wasn't that way. I discovered this along the way, and also when I started doing my own research and my PhD, of course" (Norway). 
The Professional Development of Higher Education-Based Teacher Educators: Needs and Realities

Other teacher educators were ambivalent towards the imposing research focus. Some doubted its relevance to the education of teachers, "I can see the value of more researched based knowledge. Knowledge becomes more nuanced and the understanding is elaborated. However, I am not sure that teacher education has benefitted from it" (Norway) and;

"I think you should engage with the research but it is not essential to be a good researcher in your own right, presumably we are teaching our trainees to engage and act on research and critical thinking but my feeling is that doing your own research is not essential for a good teacher / educator" (England).

Other teacher educators resisted the preferred status awarded to research over teaching, "Part of my contractual job anyway as an academic at a university. I do kind of worry a little bit that those who often talk about research do so as if it's privileged to teaching and I don't think it is. I think both are as important as each other" (England).

There was a clear frustration for a number of teacher educators that the higher education institutes' research-active rhetoric did not match the university support structures, "Our leaders in teacher education (...) are speaking in two tongues. They say 'We want you to do research' but they don't' prioritise what is necessary to get the time to do effective research" (Israel) and;

"I think there is a tension in me being a teacher educator and researcher and I think the demands of being a good teacher educator and preparing your materials, delivering them, engaging with your students takes times and I think that I speak for so many of my colleagues (...) they have had enough [of the rhetoric not matching the support]" (Scotland). 
The Professional Development of Higher Education-Based Teacher Educators: Needs and Realities

\section{Discussion}

Although research literature as well as policy documents convey an increased interest in teacher educators' role and development (European Commission, 2013, Lunenberg et al. 2014), our study revealed that there is limited interest on the part of higher education institutes in teacher educators' professional development.

\section{The Induction Period}

A level of frustration was evident when teacher educators reported that there had been an expectation on entering the teacher education profession that they had already acquired the necessary skill-set to be an effective teacher educator. The infrastructure of institutes appeared not to provide time to support or mentor beginning teacher educators, with many teacher educators reporting that they were expected to 'hit the ground running' from day one of their appointment. This finding is consistent with other reports claiming that beginning teacher educators experience a period of "de-skilling", as they try to adapt to their new roles as higher education-based teacher educators (for example, Murray \& Male 2005, Zeichner, 2005, Dinkelman et al. 2006, Harrison \&McKeon 2008). Similar to Goodwin and her colleagues (2014), our findings reveal that although these studies were published about a decade ago, none of our interviewees had a formal induction phase, and the few who had mentors relied upon informal acquaintance and personal relationships rather than institutionalized induction programmes.

Frustration and Tension in Navigating the Role of Teacher Educator 
The Professional Development of Higher Education-Based Teacher Educators: Needs and Realities

The teacher educators across the included countries confirmed the diversity of their role (Lunenberg et al. 2014). They supported, furthermore, that being a teacher educator was different from their previous roles. Being recruited from two sources, schools or universities (Vanassche et al. 2015), there are various competences in the group of teacher educators vis a vis these roles. Tensions in navigating their roles as teacher educators was evident when considering their teaching and research remits.

Teaching in higher education institutes may be significantly different from teaching in schools (Berry 2007, McKeon \& Harrison 2010). While teacher educators conveyed a passion for teaching and improving their teaching practices, it was clear that institutes preferred to invest their support and associated structures towards research activities. The pressure towards research made it difficult to focus on teaching as much as many of the teacher educators wanted to. Furthermore, we are not sure how conscious teacher educators are about what Loughran (2014) describes as the 'pedagogy of teacher education', and whether they have adopted a stance of inquiry towards their teaching (Cochran-Smith 2003).

Another clearly articulated tension concerning teaching was the elapsed time between being a teacher in a school and operating as a teacher educator, with many teacher educators suggesting that there was a need for teacher educators to ensure they found a way in which to stay updated on the realities of teaching in schools. Our findings support that teacher educators want proximity to the practice field and to develop their teaching.

Many of the more experienced teacher educators had entered the teacher education profession as practicing schoolteachers with no higher research degree. It was evident that for this specific sub-set of teacher educators, the terms of their initial appointment were somewhat dated in an 
The Professional Development of Higher Education-Based Teacher Educators: Needs and Realities

institutional climate that had changed, in some instances quite aggressively, towards research activity and research output. Interestingly, many of the same teacher educators noted the inextricable link between teaching and research, and specifically that teaching is researchinformed. However, there was less consensus on the contribution of active participation in research to educating teachers. Some teacher educators implied it was sufficient to infuse research through teaching while others believed that there was no other option than to undertake a $\mathrm{PhD}$ (if not already done so) and contribute to the institute's research metrics. A different mind-set was evident from those who had been employed more recently and had contractual obligations to be research active, with many already having a $\mathrm{PhD}$ and a developing research profile. A certain ambivalence appeared towards the type of research teacher educators should conduct. The prior survey revealed that practitioner research was one of the prioritised learning needs (Czerniawski et al. 2017). While the interviews did not highlight this, practitioner research can still be considered as a way to combine research and teaching that might add to both (Cochran-Smith 2005).

Harrison and McKeon (2008) conceive teacher educators' roles as emerging from three major components: teaching / pedagogy, research / scholarship and administrative / service. These components may support each other. For example, when achievements in research help teacher educators achieve higher status and leadership positions within their institutes, or when teacher educators study their own teaching (Cochran-Smith 2005, Loughran 2014). Some teacher educators expressed joy for having such a multi-faceted job. Nevertheless, the majority of teacher educators we interviewed felt that the three components interfered with each other and 
The Professional Development of Higher Education-Based Teacher Educators: Needs and Realities

that the end-result was work overload and lack of time for participation in professional development activities (Czerniawski et al. 2017).

\section{Haphazard Professional Learning}

There was a lack of professional learning opportunities specific to teacher educators. Some attended general courses about teaching in higher education. However, bearing in mind teacher educators' special role when teaching about teaching (Loughran 2014) and the expectation related to proximity to the practice field (Lunenberg et al. 2014), these courses did not cover what teacher educators perceived as their responsibilities. There appeared to be no considered or sequenced programme for teacher educators' professional learning which led to a somewhat haphazard approach to accessing any general professional learning opportunities when they arose. There was a clear reliance on the individual teacher educator to seek out appropriate professional learning opportunities (Tack et al. 2018). Interestingly, The Mofet institute in Israel provides diverse study programmes that are specifically tailored to teacher educators' needs (Golan \& Reichenberg 2015). Although many of the Israeli interviewees participated in some of these programmes, none of them took advantage of the formal bi-annual programmes that award teaching certificates for higher education institutes. Since previous research found that graduates of these programmes are highly satisfied (Reicengerg et al. 2015), it seems that the haphazard character of teacher educators' preparation results not only from lack of appropriate opportunities but also from lack of time and lack of institutional requirements.

\section{Learning with and from Each Other}


The Professional Development of Higher Education-Based Teacher Educators: Needs and Realities

Accessing colleagues who could support teacher educators' professional learning was a preferred way to increase teacher educators' skills and knowledge. Few teacher educators reported they participated in professional communities that played a crucial role in their capacity building (MacPhail et al. 2014, Willemse et al. 2016, Brody \& Hadar 2018). Others positioned themselves as individual academics, focusing more on individual rewards, research metrics and outputs. They appeared to favour a more informal way of connecting with colleagues when necessary and appropriate. These findings are supported by previous studies (Smith 2017, Van der Klink et al. 2017, Tack et al. 2018).

It was also evident that there was not always the opportunity to learn from colleagues in one's own institute. Some teacher educators expressed fear of competition and judgemental attitudes of their colleagues and this heightened the necessity to identify others who had a skill-set that individuals could access and learn from.

Teacher educators tended to focus on how best to gain support from more experienced colleagues than consider how they could support colleagues. Limiting institute infrastructure did not encourage or prepare formal opportunities for teacher educators to up-skill as mentors to beginning teacher educators. Nevertheless, similar to other leading teacher educators (CochranSmith 2003, Smith 2017), those who mentored other teacher educators found the experience rewarding and enriching, leading to further professional development.

\section{Conclusion}

Three main 'headlines' emerge from the study. Firstly, there appears to be an undercurrent (perpetuated by institutes and in turn individual teacher educators) that all teacher educators 
The Professional Development of Higher Education-Based Teacher Educators: Needs and Realities

excel in multiple roles and responsibilities related to teaching, research, administration and leadership. Such an undercurrent indicates an underestimation of the complexity of being a teacher educator. This assumption results in an individualistic focus on the teacher educator at the expense of considering the advantages of bringing together unique and complementary skillsets of teacher educators to work as a team of teacher educators and share the expected deliverables of a teacher educator in an academic setting. A prerequisite for sharing competencies is respect and acknowledgement of diverse competences.

Secondly, there is a strong desire from teacher educators to avail of the opportunity to learn from each other, appreciating that the pressure of finding time to meet and discuss with colleagues is a continual barrier to such aspirations. Consideration could be given to proactively recruiting teacher educators new to the profession who complement the current skill-sets of those currently in post. This would allow colleagues to acknowledge the different skill-sets each possess as well as learn from each other. The application of this recommendation requires that teacher education institutes set specific time slots for interaction and learning among colleagues. Such time slots will enable teacher educators to overcome time pressures and coordination difficulties and express the institute's support and appreciation for teacher educators' professional development.

Thirdly, the disconnect from school practice experienced by teacher educators appears, in their own minds, to diminish the currency of the teacher educator in espousing the reality of teaching in schools. Ways in which this can be addressed can be considered through shared teacher education contractual agreements and cooperation between schools and higher institutes.

It is therefore recommended that teacher educators receive mandatory formal preparation before they start working as teacher educators, and later participate in professional learning and research 
The Professional Development of Higher Education-Based Teacher Educators: Needs and Realities

communities, either within or outside their institute. Such opportunities need to be cognizant of the different backgrounds from which teacher educators are being recruited as well as the selfcontradictory expectations of teacher educators that are reported (Ulvik \& Smith 2016). It is further suggested that teacher education institutes review teacher educators' roles, and provide a structured and balanced work schedule, that allows time for professional development. As Loughran (2014) justly claims, too many of those who hold leadership roles in teacher education institutes have quit teaching for research and therefore cannot be perceived as role models. In the future, it will be interesting to follow teacher educators' professional development trajectories and compare the professional development needs and activities of higher education-based teacher educators with those who are based at schools.

\section{References}

BERA / RSA, 2014. Research and the Teaching Profession. Building the capacity for a selfimproving education system. BERA.

Berry, A., 2007. Reconceptualizing teacher educator knowledge as tensions: Exploring the tension between valuing and reconstructing experience. Studying Teacher Education, 3 $(2), 117-\quad 134$.

Berry, A., Clemans, A., and Kostogritz, S., (eds.) 2007. Dimensions of professional learning: Identities, professionalism and practice. Dordrecht: Sense Publishers.

Brody, D. and Hadar, L. L., 2018. Critical moments in the process of educational change: understanding the dynamics of change among teacher educators. European Journal of Teacher Education, 41 (1), 50-65. 
The Professional Development of Higher Education-Based Teacher Educators: Needs and Realities

Cochran-Smith, M., 2003. Learning and unlearning: the education of teacher educators. Teaching and Teacher Education, 19 (1), 5-28.

Cochran-Smith, M., 2005.Teacher educators as researchers: multiple perspectives. Teaching and Teacher Education, 21, 219-225.

Czerniawski, G., Guberman, A., and MacPhail, A., 2017. The professional developmental needs of higher education-based teacher educators: an international comparative needs analysis. European Journal of Teacher Education, 40 (1), 127-140.

Dinkelman, T., Margolis, J., and Sikkenga, K., 2006. From teacher to teacher educator: Experiences, expectations, and expatriation. Studying Teacher Education, 2, 5-23.

Elstad, E., 2010. University $\square$ based teacher education in the field of tension between the academic $\quad$ world and practical experience in school: a Norwegian case. European Journal of Teacher Education, 33 (4), 361-374.

European Commission, 2013. Supporting teacher educators for better learning outcome. Brussels: $\quad$ European Commission.

Golan, M., and Reichenberg, R., 2015. Israel's Mofet institute: "community of communities" for the creation and dissemination of knowledge of teacher education. In: S. Pinnegar, J. C. Craig, and L. Orland-Barak, eds. International teacher education: promising pedagogies (Vol. 22C). Bingley, UK: Emerald, 299-316.

Goodwin, L., et al., 2014. What should teacher educators know and be able to do? Perspectives from practicing teacher educators. Journal of Teacher Education, 65 (4), 284 - 302. 
The Professional Development of Higher Education-Based Teacher Educators: Needs and Realities

Harrison, J. and McKeon, F., 2008. The formal and situated learning of beginning teacher educators in England: identifying characteristics for successful induction in the transition from workplace in schools to workplace in higher education. European Journal of Teacher Education. $31(2), 151-168$.

Korthagen, F., and Vasalos, A., 2005. Levels in reflection: Core reflection as a means to enhance professional growth. Teachers and teaching, 11 (1), 47-71.

Loughran, J., 2013. Being a teacher educator. In: M. Ben-Peretz, S. Kleeman, R. Reichenberg, and S. Shimoni, eds. Teacher educators as members of an evolving profession. Lanham, MD: Rowman \& Littlefield Education, 9-23.

Loughran, J., 2014. Professionally developing as a teacher educator. Journal of Teacher Education, 65 (4), 271-283.

Loughran, J., and Hamilton, M. L., 2016. Developing an understanding of teacher education. In: J. Loughran and M. L. Hamilton, eds. International handbook of teacher education (Vol. 1, Ch. 1). Singapore: Springer, $2-22$.

Lunenberg, M., Korthagen, F., and Swennen, A., 2007. The teacher educator as a role model. Teaching and teacher education, 23, 586-601.

Lunenberg, M., Dengerink, J., and Korthagen, F., 2014. The professional teacher educator: Roles, behaviour, and professional development of teacher educators. Rotterdam, The Netherlands: Sense. 
The Professional Development of Higher Education-Based Teacher Educators: Needs and Realities

MacPhail, A., et al., 2014. Leading by example: teacher educators' professional learning through communities of practice. Quest, 66 (1), 39-56.

Mason, J., 1996. Qualitative Researching. London: Sage Publications.

Mockler, N., 2005. Trans/forming teachers: New professional learning and transformative teacher professionalism. Journal of In-service Education, 31, 733-46.

McKeon, F. and Harrison, J., 2010. Developing pedagogical practice and professional identities of beginning teacher educators. Professional Development in Education, 36 (1), 25-44.

Murray, J, et al., 2009. Research and teacher education in the UK: Building capacity. Teaching and Teacher Education, 25 (7), 944-950.

Murray, J., 2010. Towards a new language of scholarship in teacher educators' professional learning? Professional Development in Education, 36 (1), 13.

Murray, J., 2014. Teacher educators' constructions of professionalism: a case study. Asia-Pacific Journal of Teacher Education, 42 (1), 7-21.

Murray, J. and Male, T., 2005. Becoming a teacher educator: evidence from the field. Teaching and Teacher Education, 21 (2), 125-142.

Reichenberg, R., Avissar, G., and Sagee, R., 2015. 'I owe to my tutor much of my professional development': looking at the benefits of tutoring as perceived by the tutees. Professional Development in Education, 41 (1), 40-56. 
The Professional Development of Higher Education-Based Teacher Educators: Needs and Realities

Russell, T., 1997. How I teach IS the message. In: J. Loughran, and T. Russell, eds. Purpose, passion and pedagogy in teacher education. London/Washington, DC: Falmer Press, 3247.

Smith, K., 2011. The multi-faceted teacher educator - a Norwegian perspective. Journal of Education for Teaching, 37 (3), 337-349.

Smith, K., 2015. Mentoring. In: Mentoring for Learning. Sense Publishers, Rotterdam, 283-298.

Smith, K., 2017. Learning from the past to shape the future. European Journal of Teacher Education, 40 (5), 630-646.

Swennen, A., Jones, K., and Volman, M., 2010. Teacher educators: Their identities, sub $\square$ identities and implications for professional development. Professional Development in Education, $36(1-2), 131-148$.

Tack, H., et al., 2018. Uncovering a hidden professional agenda for teacher educators: A mixed method study on Flemish teacher educators and their professional development. European Journal of Teacher Education, 41 (1), 86-104.

Ulvik, M., and Smith, K., 2016. Å undervise om å undervise : lærerutdanneres kompetanse sett fra deres eget og fra lærerstudenters perspektiv. [Teaching about teaching. Teacher educators' competence from their own and their student teachers' perspective)].UNIPED., 39 (1).

Vanassche, E., et al., 2015. InFo-TED: Bringing policy, research and practice together around teacher educator development. In: C. Craig and L. Orland-Barak, eds. International 
The Professional Development of Higher Education-Based Teacher Educators: Needs and Realities

teacher education: Promising pedagogies (Part C). Brinkley, UK: Emerald Books, 341364.

van der Klink, M., et al., 2017. Professional development of teacher educators: what do they do? Findings from an explorative international study. Professional Development in Education, 43 (2), 163-178.

Willemse, T. M., Boei, F., and Pillen, M., 2016. Fostering teacher educators' professional development on practice-based research through communities of inquiry. Vocations and Learning, 9 (1), 85-110.

Zeichner, K., 2005. Becoming a teacher educator: a personal perspective. Teaching and Teacher Education, 21 (2), 117-124.

Zeichner, K., 2007. Accumulating knowledge across self-studies in teacher education. Journal of Teacher Education, 58 (1), 36-46. 